\title{
Status aplikanta Izby Adwokackiej w Warszawie w latach 1925-1938
}

\section{Streszczenie}

W II Rzeczypospolitej na ziemiach byłego zaboru rosyjskiego zachodziły znaczące przemiany w zakresie organizacji aplikacji adwokackiej i statusu aplikanta. Wiązały się one przede wszystkim z likwidacją aplikacji mieszanej, polegającej na konieczności odbycia najpierw aplikacji sądowej, a dopiero później adwokackiej. W konsekwencji czas aplikacji wynoszący, zgodnie ze Statutem Tymczasowym, dwa lata, został wydłużony mocą Prawa o ustroju adwokatury do lat pięciu. Aplikanci byli uważani za członków palestry, jednak ich uprawnienia były bardzo ograniczone. Do ich obowiązków należała praca w kancelarii patrona oraz uczestniczenie w zajęciach.

Słowa kluczowe: adwokat, aplikant, Izba Adwokacka w Warszawie, II Rzeczpospolita, prawo o adwokaturze, zawody prawnicze.

\section{Wprowadzenie}

Polska palestra, rozumiana jako grupa zawodowa, pojawiła się dopiero w epoce nowożytnej na przełomie XV i XVI w. Wraz z jej rozwojem stopniowo wykształcał się i precyzował status aplikantów adwokackich, określanych mianem agentów. Regulowały go kolejne konstytucje sejmowe uchwalane w 1673, 1726, 1764, 1766 i 1768 r. Aplikanci pochodzili zwykle ze stanu miejskiego, jednak coraz większe zainteresowanie szlachty zawodem adwokata odwróciło z czasem tę tendencję. Agenci kształcili się bezpośrednio u adwokatów-patronów, ucząc się przede wszystkim prawa sądowego, sporządzania pism procesowych, rozmowy z klientami i występowania przed sądem. Czas nauki nie był sprecyzowany, ale w praktyce nie przekraczał sześciu lat. Po zakończeniu nauki agent składał przysięgę i był wpisywany do regestru przy właściwym sądzie ${ }^{1}$.

1 A. Kisza, Z. Krzemiński, R. Łyczywek, Historia adwokatury polskiej, Warszawa 1995, s. 35; S. Płaza, Historia prawa w Polsce na tle porównawczym, cz. I: X-XVIII r., Kraków 2002, s. 440-441; A. Redzik, T.J. Kotliński, Historia adwokatury, Warszawa 2018, s. 64, 72-73. 
Odmiennie kształtowała się sytuacja osób, które przygotowywały się do wykonywania zawodu adwokata trybunalskiego. Osoby te były określane mianem dependentów ${ }^{2}$ i dzieliły się na dwie kategorie: wyższych (starszych, którzy odbyli czteroletnią praktykę) i niższych (młodszych). Wpis do regestru dependentów (czyli aplikantów) następował zwykle po kilkuletniej praktyce w kancelarii patrona. Początkowo możliwość pełnienia funkcji dependenta przysługiwała zarówno mieszczanom, jak i szlachcie. Stopniowo jednak prawa mieszczan ograniczano, aby odebrać je im zupełnie w $1726 \mathrm{r}$. Zmiany w tym zakresie wprowadziła ustawa o miastach królewskich, której przepisy w tej materii nie weszły jednak w życie. Wśród wymogów stawianych dependentom mieściła się znajomość łaciny, prawa rzymskiego oraz prawa polskiego. Do ich obowiązków należało głównie prowadzenie kancelarii, w tym przygotowywanie pism procesowych i uczestniczenie w posiedzeniach sądu. Aplikant zostawał adwokatem trybunalskim dopiero po wyrażeniu zgody przez swojego patrona, złożeniu przysięgi w sądzie ziemskim i uzyskaniu patentu królewskiego 3 .

Począwszy od 1776 r., podejmowane były próby zreformowania polskiej adwokatury, w tym również organizacji aplikacji adwokackiej, zakończyły się one jednak niepowodzeniem ${ }^{4}$.

W Księstwie Warszawskim adwokaci dzielili się na trzy kategorie: patronów (działających przy trybunałach cywilnych, a także sądach podsędkowskich), adwokatów (przy sądzie apelacyjnym) i mecenasów (przy sądzie kasacyjnym). Pełnienie stanowiska patrona wymagało uprzedniego ukończenia wyższych studiów prawniczych oraz zdania egzaminu asesorskiego, natomiast adwokata albo mecenasa - dodatkowo - egzaminu sędziowskiego. Pierwszy z tych egzaminów przeprowadzała komisja składająca się z trzech sędziów trybunału, drugi zaś - Najwyższa Komisja Egzaminacyjna ${ }^{5}$.

W Królestwie Polskim utrzymano podział członków palestry na kategorie: mecenasów, adwokatów, patronów i obrońców (przy sądach pokoju). Obniżano jednak wymagania stawiane kandydatom ze względu na likwidację wyższych studiów prawniczych. Od 1840 r. osoby ubiegające się o stanowiska mecenasów musiały ukończyć dodatkowo studia prawnicze (w Moskwie lub Petersburgu), ale kandydaci na funkcje adwokatów lub patronów mieli jedynie odbyć Kurs Prawa w Gimnazjum Warszawskim. Natomiast po zniesieniu tych kursów wymagano zaledwie ukończenia szkoły gubernialnej lub powiatowej i odpowiedniej praktykí6.

2 W literaturze historycznoprawnej trwa spór o znaczenie terminu „dependent”, szerzej: A. Redzik, T.J. Kotliński, Historia adwokatury, s. 73.

3 Szerzej: tamże, s. 66.

4 Szerzej: A. Kisza, Z. Krzemiński, R. Łyczywek, Historia adwokatury, s. 60 i n.; A. Redzik, T.J. Kotliński, Historia adwokatury, s. 74 i n.

5 Historia państwa i prawa Polski, t. III: Od rozbiorów do uwłaszczenia, red. J. Bardach, M. Senkowska-Gluck, Warszawa 1981, s. 127, 129-130; A. Kisza, Z. Krzemiński, R. Łyczywek, Historia adwokatury, s. 70; S. Płaza, Historia prawa w Polsce na tle porównawczym, cz. II: Polska pod zaborami, Kraków 2002, s. 192; A. Redzik, T.J. Kotliński, Historia adwokatury, s. 92-93. 
W pierwszych latach po odzyskaniu niepodległości w byłym zaborze rosyjskim obowiązywał Dekret w przedmiocie statutu tymczasowego Palestry Państwa Polskiego [dalej: Statut Tymczasowy] wydany przez Tymczasowego Naczelnika Państwa 24 grudnia 1918 r. (wszedł w życie 1 stycznia 1919 r.) ${ }^{7}$. Miał on obowiązywać do czasu ujednolicenia organizacji palestry w całym kraju, co nastąpiło dopiero mocą wzorowanego na Statucie z 1918 r. rozporządzenia Prezydenta Rzeczypospolitej z dnia 7 października 1932 r. Prawo o ustroju adwokatury ${ }^{8}$.

Statut Tymczasowy regulował organizację adwokatury na zasadach szerokiego samorządu zawodowego i choć formalnie aplikanci byli uznawani za członków palestry, nie mogli aktywnie w tym samorządzie działać. Byli co prawda uprawnieni do uczestniczenia w walnym zgromadzeniu, ale tylko za zgodą dziekana, natomiast w ogóle nie mogli się wypowiadać ani brać udziału w głosowaniach. Zbliżoną regulację wprowadziło Prawo o ustroju adwokatury, utrzymując status aplikantów jako członków palestry. Mogli oni nie tylko brać udział w walnym zgromadzeniu izby, ale nawet zabierać głos, choć w głosowaniach już nie uczestniczyli9 ${ }^{9}$.

Zagadnieniem pomijanym w literaturze historycznoprawnej jest sytuacja aplikantów adwokackich zrzeszonych w ramach poszczególnych izb, m.in. w jednej z pierwszych powołanych w II RP - Izbie Adwokackiej w Warszawie ${ }^{10}$. Na jej prześledzenie pozwalają zachowane źródła w postaci sprawozdań Rady Adwokackiej tej izby z lat 1925-1938, informujących m.in. o czasie trwania aplikacji, prawach i obowiązkach aplikantów.

\section{Czas trwania aplikacji}

Zgodnie ze Statutem Tymczasowym z 24 grudnia 1918 r. droga do zawodu adwokata wymagała nie tylko ukończenia studiów prawniczych na polskiej uczelni, ale również odbycia aplikacji mieszanej, czyli najpierw dwuletniej aplikacji sądowej, a następnie dwuletniej aplikacji adwokackiej, zakończonych kolejno właściwymi

7 Dziennik Praw Państwa Polskiego z 1918 Nr 22 poz. 75; szerzej: Z. Krzemiński, Kartki z dziejów warszawskiej adwokatury, Warszawa 2008, s. 24-25; M. Materniak-Pawłowska, Adwokatura II Rzeczypospolitej. Zagadnienia prawno-ustrojowe, Poznań 2009; A. Redzik, T.J. Kotliński, Historia adwokatury, s. 152-153, 168 i n.

8 Dz.U. 1932 Nr 86 poz. 733; S. Płaza, Historia prawa w Polsce na tle porównawczym, cz. III: Okres międzywojenny, Kraków 2001, s. 703; A. Redzik, T.J. Kotliński, Historia adwokatury, s. 169, 172 i n.

9 T.J. Kotliński, Samorzqd adwokacki w Drugiej Rzeczypospolitej, Warszawa 2008, s. 33, 69; M. Materniak-Pawłowska, Adwokatura II Rzeczypospolitej..., s. 183, 194.

10 Powołana już w lutym 1919 r. - T.J. Kotliński, Samorząd adwokacki..., s. 35; A. Redzik, T.J. Kotliński, Historia adwokatury, s. 169-170. 
egzaminami ${ }^{11}$. W praktyce pojawiły się wątpliwości dotyczące możliwości skrócenia aplikacji adwokackiej w razie odbycia dłuższej niż dwuletnia aplikacji sądowej. Jednak ewentualność taką odrzuciła ostatecznie Naczelna Rada Adwokacka [dalej: NRA] w orzeczeniu z 9 października $1926 \mathrm{r}^{12}$

Znaczącą zmianę zasad dotyczących przygotowania do zawodu adwokata wprowadziło Prawo o ustroju adwokatury z 7 października 1932 r. Przedłużyło ono czas trwania aplikacji adwokackiej do lat pięciu ${ }^{13}$. Wydłużenie tego okresu wynikało ze zniesienia obowiązku odbycia aplikacji sądowej i wprowadzenia aplikacji jednolitej ${ }^{14}$.

\section{Obowiązki aplikantów}

$\mathrm{Na}$ aplikantach ciążył, mocą art. 15 Statutu Tymczasowego, obowiązek pracy $\mathrm{w}$ kancelarii patrona oraz uczestniczenia $\mathrm{w}$ zajęciach praktycznych i teoretycznych, organizowanych przez miejscową radę adwokacką ${ }^{15}$.

Zasadę tę doprecyzowało Prawo o ustroju adwokatury z 1932 r., stanowiąc, że aplikant był zobowiązany do pracy „w kancelarii patrona i pod jego rzeczywistym kierownictwem, tudzież uczestniczyć w pracach organizowanych przez radę adwokacką celem zawodowego kształcenia aplikantów"16. Wskazywało ponadto, że „[k]ierowanie zawodowem wychowaniem i wykształceniem aplikantów należy do rady adwokackiej"17.

W związku z tym uchwałą z 6 grudnia 1932 r. Rada Adwokacka w Warszawie powołała Komisję Aplikacji Adwokackiej, której zadaniem miało być opracowanie „ogólnego programu zawodowego wychowania i wykształcenia aplikantów adwokackich" oraz planu działania w najbliższym okresie. W skład tego organu weszli: Adam Chełmoński jako przewodniczący, Jan Nowodworski, Stefan Urbanowicz,

11 Art. 3 Statutu Tymczasowego - T.J. Kotliński, Samorzqd adwokacki..., s. 36-37; M. Materniak-Pawłowska, Adwokatura II Rzeczypospolitej..., s. 181; A. Redzik, T.J. Kotliński, Historia adwokatury, s. 179.

12 Orzeczenie Naczelnej Rady Adwokackiej z dnia 9 października 1926 r., „Palestra” 1927, R. IV, nr 2, s. 66-76; Sprawozdanie Rady Adwokackiej w Warszawie za rok 1931-1932 [dalej: Sprawozdanie Rady Adwokackiej 1931-1932], Warszawa 1932, s. 76.

13 Art. 103 Prawa o ustroju adwokatury.

14 T.J. Kotliński, Samorzq̨d adwokacki..., s. 71.

15 Art. 15 Statutu Tymczasowego.

16 Art. 105 Prawa o ustroju adwokatury.

17 Art. 106 Prawa o ustroju adwokatury. 
Wacław Brokman i Zygmunt Nagórski. Rada upoważniła komisję do dokooptowania do swego składu kolejnych członków w razie zaistnienia takiej potrzeby ${ }^{18}$.

Rada uznała również za jeden $\mathrm{z}$ elementów szkolenia udział aplikantów w konsultacjach dla niezamożnej ludności. Nie mogli oni sami udzielać porad, ale asystowali dyżurującym adwokatom ${ }^{19}$.

W praktyce w kwestii realizacji obowiązku pracy w kancelarii patrona pojawiły się wątpliwości dotyczące liczby zatrudnianych aplikantów. Rada Adwokacka w Lublinie podjęła decyzję o ograniczeniu tej możliwości tylko do jednego aplikanta. Jednak NRA ustosunkowując się do tej decyzji, wydała 29 maja 1926 r. orzeczenie, w którym wskazała, że poszczególne rady nie mogą nakładać tego rodzaju limitów. Powołała się przy tym z jednej strony na brak stosownych przepisów w Statucie Tymczasowym, zaś z drugiej - na istnienie w praktyce możliwości należytego przygotowania więcej niż jednego aplikanta do egzaminu (tym samym odrzuciła argumentację lubelską). W skazała ponadto na wyczerpujące uregulowanie w Statucie Tymczasowym kwestii przygotowania aplikantów do zawodu oraz problemu odpowiedzialności tych osób, a także ich patronów ${ }^{20}$.

Po kilku latach NRA zmieniła swoje stanowisko i w uchwale z 22 marca $1930 \mathrm{r}$. wskazała, że „[a]dwokat może być patronem jednego tylko aplikanta adwokackiego. W razach wyjątkowych, zasługujących na uwzględnienie, Rada Adwokacka może zezwolić poszczególnemu adwokatowi na pracę w jego kancelarii dwóch aplikantów adwokackich"21.

Ograniczenie takie zostało przez ustawodawcę wprowadzone w art. 100 ust. 2 Prawa o ustroju adwokatury z 1932 r., zgodnie z którym adwokat mógł zatrudniać tylko jednego aplikanta. Na zatrudnienie dwóch lub większej liczby osób potrzebował zgody rady adwokackiej ${ }^{22}$.

W praktyce korzystano z takiej możliwości i w okresie 1930-1931 Rada Adwokacka w Warszawie wyraziła zgodę na zatrudnienie drugiego aplikanta w 21 przypadkach. Według danych podanych przez radę 294 patronów zatrudniało po 1 aplikancie, 65 - po 2, a 4 - po 3 aplikantów ${ }^{23}$. Przyrosty następujące w kolejnych latach obrazuje tabela 1 .

18 Sprawozdanie Rady Adwokackiej w Warszawie za rok 1932-1933 [dalej: Sprawozdanie Rady Adwokackiej 1932-1933], Warszawa 1933, s. 9.

19 Sprawozdanie Rady Adwokackiej w Warszawie za rok 1925-26 (za czas od IV 1925 do 1 IV 1926) [dalej: Sprawozdanie Rady Adwokackiej 1925-1926], Warszawa 1926, s. 53.

20 Sprawozdanie Rady Adwokackiej w Warszawie za rok 1927-28 (za czas od I IV 1927 do 1 IV 1928 r.) [dalej: Sprawozdanie Rady Adwokackiej 1927-1928], Warszawa 1928, s. 57; Komunikat nr 34 w przedmiocie ograniczenia aplikantów w wyborze patrona lub też adwokatów w przyjmowaniu tej lub innej liczby aplikantów, „Palestra” 1926, R. III, nr 6, s. 292.

21 Komunikat nr 94 w sprawie ograniczeń co do podejmowania się przez adwokatów obowiq̨zków patronów, „Gazeta Sądowa Warszawska” 1930, nr 17, s. 246; Sprawozdanie Rady Adwokackiej w Warszawie za rok 1930-1931 [dalej: Sprawozdanie Rady Adwokackiej 1930-1931], Warszawa 1931, s. 79; Zatrudnienie aplikantów adwokackich, „Palestra” 1930, R. VII, nr 5, s. 223-224.

22 Art. 100 ust. 2 Prawa o ustroju adwokatury z 1932 r.

23 Sprawozdanie Rady Adwokackiej 1930-1931, s. 80-81. 
Tabela 1. Liczba adwokatów zatrudnianych przez patronów

\begin{tabular}{|c|c|c|c|}
\hline $\begin{array}{c}\text { Okres } \\
\text { sprawozdawczy }\end{array}$ & $\begin{array}{c}\text { Liczba adwokatów } \\
\text { zatrudniających } \\
\text { 1 aplikanta }\end{array}$ & $\begin{array}{c}\text { Liczba adwokatów } \\
\text { zatrudniających } \\
\text { 2 aplikantów }\end{array}$ & $\begin{array}{c}\text { Liczba adwokatów } \\
\text { zatrudniających } \\
\text { 3 aplikantów }\end{array}$ \\
\hline $1931-1932$ & 341 & 52 & - \\
\hline $1932-1933$ & 450 & 65 & 2 \\
\hline $1933-1934$ & 517 & 89 & - \\
\hline $1934-1935$ & 586 & 91 & - \\
\hline $1935-1936$ & 595 & 78 & - \\
\hline $1936-1937$ & 698 & 79 & - \\
\hline $1937-1938$ & 689 & 70 & - \\
\hline
\end{tabular}

Źródto: Sprawozdanie Rady Adwokackiej w Warszawie za rok 1930-1931, Warszawa 1931, s. 80-81; Sprawozdanie Rady Adwokackiej w Warszawie za rok 1931-1932, Warszawa 1932, s. 74; Sprawozdanie Rady Adwokackiej w Warszawie za rok 1932-1933, Warszawa 1933, s. 91; Sprawozdanie Rady Adwokackiej w Warszawie za rok 1933-1934, Warszawa, s. 85; Sprawozdanie Rady Adwokackiej w Warszawie za rok 1934-1935, Warszawa 1935, s. 93; Sprawozdanie Rady Adwokackiej w Warszawie za rok 1935-1936, Warszawa 1936, s. 109; Sprawozdanie Rady Adwokackiej w Warszawie za rok 1936-1937, Warszawa 1937, s. 102; Sprawozdanie Rady Adwokackiej w Warszawie za okres 1 XII 1937- 1 VI 1938, Warszawa 1938, s. 59.

Z tych danych wynika, że o ile początkowo liczba adwokatów zatrudniających 2 aplikantów wzrosła niemal dwuipółkrotnie (z 21 w latach 1930-1931 do 52 w latach 1931-1932), o tyle w późniejszym okresie przyrosty te nie były już tak gwałtowne. Ostatecznie zaś liczba ta wykazywała tendencję malejącą. Natomiast zatrudnianie 3 aplikantów miało charakter zupełnie wyjątkowy.

Potrzebę zatrudnienia drugiego aplikanta adwokaci najczęściej uzasadniali zbliżaniem się końca okresu aplikacji dotychczasowego aplikanta i przygotowywaniem się przez niego do egzaminu adwokackiego ${ }^{24}$. W praktyce decyzje takie podejmowali adwokaci prowadzący większą liczbę spraw ${ }^{25}$.

Istniały również wątpliwości dotyczące osiedlania się aplikantów poza siedzibą patrona. Swoje stanowisko Rada Adwokacka w Warszawie formułowała następująco:

Sprawa osiedlania się aplikantów adwokackich poza siedzibą patrona i możności prowadzenia tam przez nich praktyki na zasadzie substytucji patrona była już poprzednio parokrotnie poruszana tak przez aplikantów adwokackich, jak też i przez ich patronów-adwokatów. W roku sprawozdawczym sprawa ta była przedmiotem szczegółowych rozważań Rady Adwokackiej, która mając na względzie, że w myśl np. 15 Statutu Tymczasowego P. P. P. aplikant adwokacki obowiązany jest pracować $\mathrm{w}$ kancelarii patrona, z czego wynika, że w zasadzie aplikant powinien zamieszkiwać w miejscu zamieszkania swego patrona, że jednak wobec braku wyraźnego

24 Sprawozdanie Rady Adwokackiej 1931-1932, s. 673.

25 S. Płaza, Historia prawa..., cz. III, s. 724. 
zakazu, zamieszkanie aplikanta adwokackiego w innej miejscowości poza siedzibą patrona i zastępstwo w tej miejscowości swojego patrona pod ścisłą kontrolą tego ostatniego, należy uznać za dopuszczalne, że taka interpretacja np. 15 Statutu Tymczasowego Palestry P. P. zgodna jest z intencją ogółu adwokatury, wyrażoną w niejednokrotnych uchwałach o osiedlaniu się adwokatów na prowincji, że wreszcie interpretacja ta znalazła swój wyraz w np. 63 projektu Ustawy o urządzeniu adwokatury (wydawnictwo Komisji Kodyfikacyjnej, Tom I, zeszyt 4), Rada Adwokacka postanowiła uznać, iż nie ma przeszkód, ażeby z zastrzeżeniem wszystkich obowiązków patrona aplikanci adwokaccy zamieszkiwali na prowincji poza siedzibą patrona i prowadzili tam sprawy pod ścisłą kontrolą patrona i jego odpowiedzialnością ${ }^{26}$.

Zatem Rada Adwokacka w Warszawie uznawała racjonalnie, że aplikanci mogli osiedlać się poza siedzibą patrona. Mieli jednak podlegać jego ścisłej kontroli.

\section{Sposób kształcenia}

W myśl przepisów Statutu Tymczasowego kierowanie wykształceniem zawodowym aplikantów oraz egzaminami należało do właściwej rady adwokackiejej. Jednak ustalaniem programu zajęć i egzaminu miała zajmować się już NRA ${ }^{28}$.

Zasady te zmieniło Prawo o ustroju adwokatury z 1932 r., które przyznało szersze uprawnienia poszczególnym radom, osłabiając tym samym kompetencje NRA. Do jej zadań należało już tylko „ustalanie jednolitych zasad [...] organizacji zawodowego kształcenia aplikantów"29.

\subsection{Organizacja zajęć}

Statut Tymczasowy powierzył radzie adwokackiej organizowanie zajęć teoretycznych i praktycznych, zaś aplikantów zobowiązywał do uczestniczenia w nich ${ }^{30}$. Miało to służyć jak najlepszemu przygotowaniu do egzaminu adwokackiego i do rzetelnego wykonywania zawodu w przyszłości. Rada Adwokacka w Warszawie, dążąc do realizacji swoich zadań, w latach 1925-1926 przedsięwzięła reformę trybu prowadzenia seminariów dla aplikantów. Projektowane przez nią zmiany miały

26 Sprawozdanie Rady Adwokackiej w Warszawie za rok 1929-1930 (za czas od 15 II 1929 do 15 II 1930 r.) [dalej: Sprawozdanie Rady Adwokackiej 1929-1930], Warszawa 1930, s. 35.

27 Art. 24 Statutu Tymczasowego.

28 Art. 31 pkt e) Statutu Tymczasowego.

29 Art. 3 pkt 5, art. 37 i art. 48 pkt 3 rozporządzenia Prezydenta Rzeczypospolitej z dnia 7 października 1932 r. Prawo o ustroju adwokatury; A. Redzik, T.J. Kotliński, Historia adwokatury, s. 195.

30 Art. 15 Statutu Tymczasowego. 
polegać na podziale aplikantów na zespoły i prowadzeniu zajęć, w tym wykładów i zajęć praktycznych, w mniej licznych grupach oraz skłonieniu większej liczby adwokatów do ich przygotowywania, a wreszcie „ożywieniu i urozmaiceniu programu zajęć"'s1.

Te projekty udało się częściowo zrealizować w odniesieniu do aplikantów działających w Warszawie. Początkowo zostali oni podzieleni na cztery grupy, ale ze względu na problemy występujące w praktyce („brak odpowiedniego pomieszczenia i prowadzących") zajęcia były prowadzone w dwóch połączonych grupach ${ }^{32}$.

W kolejnych latach podejmowano dalsze starania o jak najlepszą organizację zajęć dla aplikantów. W tym celu rada adwokacka przeprowadziła konsultacje przede wszystkim w ramach zorganizowanej we wrześniu 1927 r. konferencji z członkami rady i innymi członkami Izby Adwokackiej w Warszawie, a następnie także podczas zebrania $\mathrm{z}$ aplikantami. Większość postulatów pokrywała się z zamierzeniami wcześniejszymi. Natomiast nowością było dążenie do prowadzenia zajęć praktycznych ${ }^{33}$.

W tym okresie ćwiczenia były już prowadzone w czterech grupach ${ }^{34}$. Przy czym w dwóch najbardziej zaawansowanych polegały one na rozwiązywaniu kazusów z zakresu prawa cywilnego (materialnego i procesowego) oraz handlowego, w kolejnej - z prawa karnego, zaś w ostatniej - z prawa administracyjnego ${ }^{35}$.

Od jesieni 1929 r. znowu zmniejszono liczbę grup, tym razem do trzech: „najmłodsi pod względem stage'u aplikanci przydzieleni zostali do seminarium prawa karnego, średni - do seminarium prawa administracyjnego i najstarsi - do seminarium prawa cywilnego"36. Jednak na podstawie dostępnego materiału źródłowego trudno ustalić przyczyny takiego postępowania. Mogły być nimi trudności organizacyjne związane z brakiem kadry, która zgodziłaby się prowadzić zajęcia, bo z pewnością nie wynikało to ze zbyt małej liczby aplikantów.

W związku z wydaniem przez prezydenta w 1932 r. Prawa o ustroju adwokatury, które stanowiło, że „kierowanie zawodowem wychowaniem i wykształceniem aplikantów należy do rady adwokackiej" ${ }^{37}$, Rada Adwokacka w Warszawie została zmuszona do przeprowadzenia kolejnej reformy w zakresie prowadzenia zajęć.

31 Sprawozdanie Rady Adwokackiej 1925-26, s. 52.

32 Tamże.

33 Sprawozdanie Rady Adwokackiej 1927-28, s. 53.

34 Tamże, s. 54.

35 „Przedmiotem dyskusji były zagadnienia ze wszystkich niemal dziedzin prawa cywilnego, jako to z prawa familijnego (sprostowanie aktów stanu cywilnego, zaprzeczenie prawości rodu), z prawa rzeczowego (służebność widoku i światła), z prawa zobowiązaniowego (kupno-sprzedaż, jakby umowy i jakby występki), z prawa spadkowego (odwołanie testamentów); dalej, poza luźnemi zagadnieniami z prawa autorskiego, szczególnie wyczerpująco omawiano prawo wekslowe i czekowe. W zakresie prawa formalnego najwięcej czasu i uwagi poświęcono postępowaniu upadłościowemu w związku z nowelą o odroczeniu wypłat. Przed feriami ma być omówione postępowanie egzekucyjne względem nieruchomości” - tamże.

36 Sprawozdanie Rady Adwokackiej 1929-1930, s. 38.

37 Art. 106 Prawo o ustroju adwokatury. 
Opracowaniem jej założeń miała zająć się powołana przez radę 6 grudnia 1932 r. Komisja Aplikacji Adwokackiej. W jej skład wchodzili: Adam Chełmoński jako przewodniczący, Jan Nowodworski, Stefan Urbanowicz, Wacław Brokman i Zygmunt Nagórski. Ponadto komisja mogła dokooptować do swego grona kolejne osoby, o ile zaistniałaby taka potrzeba ${ }^{38}$.

Komisja przygotowała projekt, który następnie został zaakceptowany przez radę uchwałą z 19 września 1933 r. Reforma zakładała przede wszystkim utworzenie czterech grup seminaryjnych: dwóch, w których miały być prowadzone zajęcia z prawa cywilnego (materialnego i procesowego), handlowego i ustroju sądów, jednej grupy - z zajęciami z prawa karnego (materialnego i procesowego) i organizacji adwokatury oraz jednej - z zajęciami z prawa administracyjnego. Zajęcia w każdej z tych grup miały być prowadzone przez rok, według ściśle określonego programu. Aplikant musiał odbyć zajęcia we wszystkich grupach, ale nie narzucano mu ich kolejności, zatem sam mógł dokonać wyboru ${ }^{39}$.

Ponadto reforma zakładała utworzenie „seminariów wyższych”, poruszających wybrane zagadnienia na bardziej zaawansowanym i szczegółowym poziomie. Udział w nich nie miał jednak charakteru obligatoryjnego ${ }^{40}$.

Nowe zasady miały obowiązywać od początku 1934 r. $^{41}$, przy czym kierownictwo nad poszczególnymi grupami zostało ustalone uchwałą Rady Adwokackiej z 12 grudnia 1933 r. Objęli je odpowiednio: grupa I (prawo cywilne materialne) - Wacław Mińkiewicz, grupa II (prawo cywilne procesowe i handlowe) - Stanisław Janczewski, grupa III (prawo karne) - Jan Nowodworski i Antoni Landau, grupa IV (prawo administracyjne) - Stefan Urbanowicz ${ }^{42}$.

Wdrożenie reformy wymagało jeszcze powołania sekretarzy grup oraz ich zastępców, stosownie do $\$ 99$ regulaminu. Kandydatów na te stanowiska wskazało Ogólne Zebranie Aplikantów 26 maja 1934 r., a rada adwokacka powołała ich uchwałą z 6 listopada tego samego roku. Zostali nimi: Wiesław Szpakowicz - sekretarz grupy I, Witold Łyżwiński - jego zastępca, Władysław Talmont - sekretarz grupy II, Jerzy Jodłowski - zastępca, Leon Leszek Sokołowski - sekretarz grupy III, Tadeusz Doberski - zastępca, Bronisław Wertheim - sekretarz grupy IV oraz Izaak Finkelsztein - zastępca ${ }^{43}$.

W kolejnych latach Komisja Aplikacji Adwokackiej w dalszym ciągu pracowała nad zmianami, mającymi na celu poprawę warunków kształcenia aplikantów. W 1936 r. przygotowała ona postulaty, obejmujące przede wszystkim podział dotychczasowych czterech grup seminaryjnych i utworzenie z ich członków aż ośmiu docelowych grup zasadniczych. Wnioskowała również o zorganizowanie zajęć

38 Sprawozdanie Rady Adwokackiej 1932-1933, s. 9.

39 Sprawozdanie Rady Adwokackiej 1932-1933, s. 92.

40 Tamże.

41 Sprawozdanie Rady Adwokackiej 1932-1933, s. 93.

42 Sprawozdanie Rady Adwokackiej w Warszawie za rok 1933-1934 [dalej: Sprawozdanie Rady Adwokackiej 1933-1934], Warszawa 1934, s. 8.

43 Tamże, s. 88. 
seminaryjnych o charakterze ogólnym, poświęconych tematyce: prawa o ustroju adwokatury, historii adwokatury i stosowania prawa z punktu widzenia etyki ${ }^{44}$. Zajęcia takie zostały zorganizowane i były prowadzone $\mathrm{w}$ ramach piątej grupy ${ }^{45}$.

Przeprowadzono również podział czterech grup na osiem mniejszych podgrup, jednak ostatecznie 7 października 1937 r. na zebraniu, w którym uczestniczyli: dziekan rady i kierownicy poszczególnych seminariów, zrezygnowano z niego, uzasadniając, że „podział grup zasadniczych na podgrupy nie dał zamierzonych wyników, a znacznie utrudnił zapewnienie potrzebnej ilości wykładowców z uwagi na potrzebę równoległych wykładów z tych samych przedmiotów"46.

Odnosząc się do kwestii nauczanych przedmiotów, można wskazać, że początkowo zajęcia dotyczyły: prawa karnego i procedury karnej, prawa cywilnego i procedury cywilnej, prawa handlowego, prawa administracyjnego, ustroju adwokatury i etyki zawodowej ${ }^{47}$. W 1928 r. zaczęto także prowadzić wykłady z historii adwokatury na ziemiach polskich i za granicąa ${ }^{48}$. Potem nauczano również prawa prywatnego międzynarodowego oraz międzydzielnicowego ${ }^{49}$. Baczną uwagę zwracano przede wszystkim na zmieniające się przepisy ${ }^{50}$.

Jako przykład zajęć zorganizowanych dla aplikantów można wskazać plan przygotowany na okres 1930/1931:

„Seminaria dla aplikantów adwokackich w Warszawie na okres 1930/31 obejmować będą wykłady oraz zajęcia praktyczne z zakresu prawa karnego, administracyjnego, cywilnego i handlowego [...]. Plan zajęć seminaryjnych, poczynając od dn. 1 maja 1930 r., jest następujący:

Grupa I. Seminaria prawa karnego. Zajęcia odbywać się będą w poniedziałki o godz. 20 1 1/2 w gmachu Sądu Apelacyjnego.

Grupa II. Seminaria prawa administracyjnego. Zajęcia odbywać się będą w poniedziałki o godz. 20 1⁄2 w lokalu Towarzystwa Prawniczego (ul. Kredytowa Nr. 3) według następującego programu:

\begin{tabular}{|c|c|c|}
\hline Data & \multicolumn{1}{|c|}{ Przedmiot } & Kierownik \\
\hline 1 & 2 & 3 \\
\hline $8 \mathrm{~V}$ & $\begin{array}{l}\text { Pojęcie administracji i prawa adm. Przepisy o admin. } \\
\text { w konstytucji i inne źródła prawa adm. Organizacja władz } \\
\text { admin. politycznych i policyjnych }\end{array}$ & Adw. St. Urbanowicz \\
\hline
\end{tabular}

44 Sprawozdanie Rady Adwokackiej w Warszawie za rok 1935-1936 [dalej: Sprawozdanie Rady Adwokackiej 1935-1936], Warszawa 1936, s. 119.

45 Sprawozdanie Rady Adwokackiej w Warszawie za rok 1936-1937 [dalej: Sprawozdanie Rady Adwokackiej 1936-1937], Warszawa, s. 108.

46 Tamże.

47 Sprawozdanie Rady Adwokackiej 1925-1926, s. 52.

48 Sprawozdanie Rady Adwokackiej 1927-1928, s. 55.

49 Sprawozdanie Rady Adwokackiej 1931-1932, s. 74.

50 Sprawozdanie Rady Adwokackiej 1929-1930, s. 38. 


\begin{tabular}{|c|c|c|}
\hline 1 & 2 & 3 \\
\hline $15 \mathrm{~V}$ & Zasady ogólnego postępowania admin. & $"$ \\
\hline $22 \mathrm{~V}$ & $", "$, & $”$ \\
\hline $3 \mathrm{VI}$ & $\begin{array}{l}\text { Zasady sądownictwa administracyjnego ze szczególnem } \\
\text { uwzględnieniem postępowania przed Najwyższym } \\
\text { Trybunatem Administracyjnym }\end{array}$ & Adw. Józef Kuczyński \\
\hline $12 \mathrm{VI}$ & $", "$, & 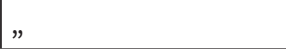 \\
\hline $26 \mathrm{VI}$ & $\begin{array}{l}\text { Rozpoznanie praktycznych przykładów skarg do } \\
\text { Najwyższego Trybunału Administracyjnego }\end{array}$ & $"$ \\
\hline $3 \mathrm{VII}$ & Postępowanie administracyjno-karne & $"$ \\
\hline $11 \mathrm{IX}$ & Pojęcie swobodnego uznania władz administracyjnych & $\begin{array}{l}\text { Adw. Aleksander } \\
\text { Kroński }\end{array}$ \\
\hline $18 I X$ & Zasady i źródła ustawodawstwa samorządowego & $"$ \\
\hline $25 \mathrm{IX}$ & $\begin{array}{l}\text { Przepisy, dotyczące stowarzyszeń, związków } \\
\text { (zawodowych), prawa koalicji oraz ustawodawstwo } \\
\text { wyjątkowe }\end{array}$ & Adw. Józef Kliński \\
\hline $2 x$ & Przepisy, dotyczące prawa obywatelstwa & $\begin{array}{l}\text { Adw. Szymon } \\
\text { Rundsztejn }\end{array}$ \\
\hline $9 x$ & $", ", "$ & $”$ \\
\hline $16 x$ & $\begin{array}{l}\text { Ustawodawstwo agrarne (reforma rolna) i przepisy } \\
\text { o przenoszeniu prawa własności na maj. ziemskie, przepisy } \\
\text { o komasacji i regulacji serwitutów, z uwzględnieniem } \\
\text { przepisów prawnych o organizacji włościan. Organizacja } \\
\text { władz ziemskich i postępowanie przed niemi. Przepisy, } \\
\text { dotyczące instytucji kredytu rolnego. Ustawodawstwo leśne }\end{array}$ & $\begin{array}{l}\text { Adw. Zygmunt } \\
\text { Nagórski }\end{array}$ \\
\hline $23 x$ & $", "$, & $"$ \\
\hline $30 x$ & $", "$, & $"$ \\
\hline $6 \mathrm{XI}$ & $\#, "$, & $"$ \\
\hline $13 \mathrm{XI}$ & Ustawodawstwo podatkowo-skarbowe & $\begin{array}{l}\text { Adw. Wład. } \\
\text { Szatensztejn }\end{array}$ \\
\hline $20 X I$ & $", "$, & $"$ \\
\hline $27 \mathrm{XI}$ & $", "$, & $"$ \\
\hline $4 \mathrm{XII}$ & $", \#$, & $"$ \\
\hline $11 \mathrm{XII}$ & Ustawodawstwo socjalne & Adw. Józef Kliński \\
\hline $18 \mathrm{XII}$ & $", "$, & $"$ \\
\hline 8131 & $\begin{array}{l}\text { Przepisy, dotyczące ograniczenia prawa własności } \\
\text { (wywłaszczenia na cele użyteczności publicznej, } \\
\text { ograniczające przenoszenie prawa własności } \\
\text { nieruchomości cudzoziemców w b. zaborze pruskim, } \\
\text { b. obywateli imperium rosyjskiego i t. d.) }\end{array}$ & $\begin{array}{l}\text { Adw. Stefan } \\
\text { Urbanowicz }\end{array}$ \\
\hline
\end{tabular}


Grupa III. Seminarium prawa cywilnego i handlowego. Zajęcia odbywać się będą w środy o godz. 20 1/2 w lokalu Towarzystwa Prawniczego (Kredytowa 3) na razie według następującego programu:

\begin{tabular}{|c|c|c|}
\hline Data & Przedmiot & Kierownik \\
\hline $7 \mathrm{~V}$ & Formy zabezpieczenia umów & Adw. Leon Nowodworski \\
\hline $14 \mathrm{~V}$ &,$\eta$, & $"$ \\
\hline $21 \mathrm{~V}$ & $\begin{array}{l}\text { Prawo spadkowe (spadkobranie beztestamentowe, } \\
\text { testamenty i darowizny) }\end{array}$ & Adw. Antoni Bogucki \\
\hline $28 \mathrm{~V}$ & $\#, "$, & $"$ \\
\hline $4 \mathrm{VI}$ & $, ",$, & $"$ \\
\hline $11 \mathrm{VI}$ & Sądownictwo polubowne & Adw. Roman Kuratowski \\
\hline $18 \mathrm{VI}$ & $\#, "$, & $"$ \\
\hline $25 \mathrm{VI}$ & 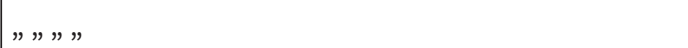 & $"$ \\
\hline
\end{tabular}

Dalszy program będzie obwieszczony dodatkowo" 51 .

Rada Adwokacka w Warszawie przestrzegała przepisów dotyczących obowiązku uczestniczenia przez aplikantów w zajęciach, odnosząc jednak tę powinność wyłącznie do osób zamieszkałych w stolicy. Nieusprawiedliwione nieobecności były surowo karane i skutkowały pociąganiem do odpowiedzialności dyscyplinarnej ${ }^{52}$. Na przykład w okresie 1930-1931 rada adwokacka stosowała w przypadku nieusprawiedliwionych nieobecności na zajęciach seminaryjnych konsekwencje w postaci przedłużania okresu aplikacji (na podstawie art. 19 Statutu Tymczasowego) ${ }^{53}$.

\subsection{Zajęcia dla aplikantów spoza Warszawy}

Organizacja zajęć dla osób odbywających aplikację poza Warszawą stanowiła poważną trudność. Początkowo w badanym okresie - w latach 1925-1926 - nie odbywały się żadne seminaria dla osób spoza stolicy ${ }^{54}$. Problemowi temu próbowano zaradzić w kolejnych latach, zwłaszcza że, jak podkreślała Rada Adwokacka w Warszawie: „aplikanci adwokaccy, odbywający praktykę na prowincji, wykazują zazwyczaj znacznie gorsze przygotowanie aniżeli aplikanci warszawscy"55. Plany obejmowały organizację zajęć w tych ośrodkach, w których była większa liczba

51 Komunikat nr 97 w sprawie rozkładu zajęć w seminariach dla aplikantów adwokackich na okres 1930/31, „Palestra” 1930, R. VII, nr 6-7, s. 333-335.

52 Sprawozdanie Rady Adwokackiej 1925-1926, s. 52.

53 Sprawozdanie Rady Adwokackiej 1930-1931, s. 83.

54 Sprawozdanie Rady Adwokackiej 1925-1926, s. 53.

55 Sprawozdanie Rady Adwokackiej 1930-1931, s. 84. 
aplikantów. Seminaria przez pewien czas były prowadzone w Łodzi (do której dojeżdżali na zajęcia również aplikanci z Kalisza), jednak zaniechano ich z uwagi na brak prowadzących. W związku z tym seminaria w latach 1930-1931 w dalszym ciągu odbywały się jedynie w stolicy.

W okresie 1931-1932, jak wskazywali delegaci rady adwokackiej na prowincji, seminaria nie były organizowane ze względu na małą liczbę aplikantów ${ }^{56}$. Potwierdza to sprawozdanie na dzień 1 marca 1932 r.: w miastach będących siedzibami sądów okręgowych (z wyjątkiem Łodzi) było łącznie 33 aplikantów, a w pozostałych miejscowościach - 18, dlatego zorganizowanie dla nich zajęć mogło być trudne. Należy jednak podkreślić, że w Łodzi było aż 66 aplikantów, zatem przygotowanie dla nich ćwiczeń było jak najbardziej celowe i potrzebne, a informacja o zbyt małej liczbie osób stanowiła zapewne jedynie wymówkę ${ }^{57}$.

W kolejnym (1933) roku prowadzono zajęcia dla aplikantów w Białymstoku, przy czym poza aplikantami adwokackimi uczestniczyli w nich również aplikanci sądowi ${ }^{58}$. Zorganizowano również seminaria $\mathrm{w}$ Łodzi, które prowadzono także w kolejnych latach ${ }^{59}$.

\subsection{Wykładowcy}

Zajęcia dla aplikantów prowadzili przede wszystkim członkowie Rady Adwokackiej w Warszawie (np. kolejni dziekani: Zygmunt Sokołowski, Jan Nowodworski ${ }^{60}$, Bolesław Bielawski ${ }^{61}$ ), ale rada zachęcała do udziału w szkoleniach również innych członków Izby.

Wśród wykładowców można odnaleźć wybitnych przedstawicieli palestry. Jednym z nich był Ludwik Domański ${ }^{62}$, od 1919 r. członek Wydziału Cywilnego Komisji Kodyfikacyjnej Rzeczypospolitej Polskiej, autor licznych prac naukowych z zakresu prawa cywilnego, pełniący w latach 1935-1939 stanowisko prezesa Naczelnej Rady Adwokackiej, a po II wojnie światowej wykładowca Uniwersytetu Łódzkiego ${ }^{63}$.

56 Sprawozdanie Rady Adwokackiej 1931-1932, s. 75-76. W sprawozdaniu wskazano, że zorganizowano zaledwie jeden odczyt (z zakresu prawa administracyjnego) w Sosnowcu, tamże, s. 76.

57 Tamże, s. 65.

58 Sprawozdanie Rady Adwokackiej 1932-1933, s. 94.

59 Sprawozdanie Rady Adwokackiej 1933-1934, s. 89; Sprawozdanie Rady Adwokackiej w Warszawie za rok 1934-1935 [dalej: Sprawozdanie Rady Adwokackiej 1934-1935], Warszawa 1935, s. 97; Sprawozdanie Rady Adwokackiej 1935-1936, s. 121.

60 Sprawozdanie Rady Adwokackiej 1925-1926, s. 52-53; A. Redzik, T.J. Kotliński, Historia adwokatury, s. 204.

61 Sprawozdanie Rady Adwokackiej 1931-1932, s. 12.

62 Sprawozdanie Rady Adwokackiej w Warszawie za rok 1928-1929 (za czas od 1 III 1928 do 15 II 1929 r.) [dalej: Sprawozdanie Rady Adwokackiej 1928-1929], Warszawa 1929, s. 31.

63 A. Redzik, T.J. Kotliński, Historia adwokatury, s. 198. 
Seminaria prowadził również Zygmunt Nagórski ${ }^{64}$ - wicedziekan Rady Adwokackiej w Warszawie, członek Komisji Kodyfikacyjnej RP, wykładowca Uniwersytetu Warszawskiego, a po wojnie - polskiego Wydziału Prawa Uniwersytetu w Oxfordzie ${ }^{65}$.

Kolejnym wykładowcą był Szymon Rundstein ${ }^{66}$, członek polskiej delegacji na konferencji pokojowej w Paryżu i na rokowaniach w Berlinie w 1919 r., kierownik Katedry Prawa Narodów Wolnej Wszechnicy Polskiej w Warszawie (w latach 1921-1927), autor licznych prac naukowych z zakresu teorii prawa, prawa prywatnego, procesowego oraz międzynarodowego ${ }^{67}$.

Nie sposób również pominąć Adama Słomińskiego, Aleksandra Mogilnickiego ${ }^{68}$, Stefana Urbanowicza, Antoniego Chmurskiego ${ }^{69} \mathrm{czy}^{2}$ Leona Nowodworskiego ${ }^{70}$.

\subsection{Inicjatywa aplikantów}

Aplikanci sami zainteresowani byli pogłębianiem swojej wiedzy. W 1934 r. koła aplikantów wystąpiły do Rady Adwokackiej w Warszawie z inicjatywą samodzielnego organizowania seminariów, które miałyby się odbywać niezależnie od zajęć prowadzonych przez radę. Seminaria te, w zamyśle wnioskodawców, dotyczyłyby różnych dziedzin prawa, referaty wygłaszaliby sami członkowie i odbywałyby się one pod nadzorem adwokata posiadającego zgodę rady. Z każdych zajęć należałoby złożyć radzie listę obecności oraz wykaz wystąpień. Uczestnictwo w nich miało zwalniać z seminariów ogólnych poruszających te same zagadnienia ${ }^{71}$.

Rada adwokacka uchwałą z 18 grudnia 1934 r. zaakceptowała tę propozycję, wyrażając zgodę na prowadzenie takich zajęć $\mathrm{w}$ ramach próby. Zgodnie $\mathrm{z}$ decyzją tego organu:

I. Zajęcia seminaryjne podgrupowe przeznaczone są dla aplikantów adwokackich, pragnących drogą pracy indywidualnej pogłębić znajomość przedmiotów, wchodzących w zakres seminarium ogólnego.

II. Seminarja podgrupowe prowadzone są pod kierunkiem członka Izby, wyznaczonego w tym celu przez Radę Adwokacką.

III. Ilość członków seminarjum w podgrupie nie może przekraczać 15.

IV. Program seminarjum podgrupowego winien być uzgodniony z kierownikiem właściwej grupy ogólnej.

V. Seminarja podgrupowe mają charakter zastępczy w stosunku do seminarjum ogólnego (grupowego) pod warunkiem wykazania przez uczestników stałej obecności na zajęciach,

64 Sprawozdanie Rady Adwokackiej 1927-1928, s. 55.

65 A. Redzik, T.J. Kotliński, Historia adwokatury, s. 224.

66 Sprawozdanie Rady Adwokackiej 1927-1928, s. 55.

67 A. Redzik, T.J. Kotliński, Historia adwokatury, s. 245-246.

68 Sprawozdanie Rady Adwokackiej 1934-1935, s. 94.

69 Sprawozdanie Rady Adwokackiej 1927-1928, s. 55.

70 Sprawozdanie Rady Adwokackiej 1928-1929, s. 31.

71 Sprawozdanie Rady Adwokackiej 1933-1934, s. 88. 
które winny się odbywać nie rzadziej niż raz w tygodniu, oraz złożenia kierownikowi właściwej grupy ogólnej przez każdego uczestnika przynajmniej jednego referatu, przyjętego przez kierownika podgrupy ${ }^{72}$.

Zorganizowane zostały zajęcia z zakresu prawa cywilnego, obejmujące część ogólną kodeksu zobowiązań, oraz seminaria dotyczące prawa handlowego, których przedmiotem była część I kodeksu handlowego. Kierownictwo objęli odpowiednio Adam Słomiński i Aleksander Jackowski, zaś ogólny nadzór nad zajęciami sprawował Stanisław Janczewski. Rada adwokacka pozytywnie oceniła organizację i przebieg zajęć, podkreślając, że „małe grupy dają, oczywiście, możność bardziej intensywnej i indywidualnej pracy, a jednocześnie pozwalają uczestnikom na korzystanie w szerszej mierze $\mathrm{z}$ wiedzy kierownika”. W związku z tym Zrzeszenie Aplikantów Adwokackich wystąpiło z wnioskiem o kontynuowanie zajęć w tej formie $e^{73}$.

Również w 1936 r. Komisja Aplikacji Adwokackiej pozytywnie oceniła seminaria prowadzone na tych zasadach i postulowała dalsze ich organizowanie ${ }^{74}$.

\section{Problem aplikacji pozornej}

Jednym z poważnych problemów było zjawisko tzw. aplikacji pozornej, polegającej na niewypełnianiu obowiązków przez aplikanta. Rada Adwokacka w Warszawie próbowała temu przeciwdziałać, zobowiązując patronów do składania sprawozdań półrocznych z działalności i postępów ich aplikantów oraz informując adwokatów o uchybieniach aplikantów, pociąganiu ich do odpowiedzialności, dopuszczaniu do egzaminów i in. ${ }^{75}$ Sprawozdania patroni mieli składać w terminach: 1-15 kwietnia i 1-15 października każdego roku ${ }^{76}$.

Aby ujednolicić treść składanych dokumentów, 22 listopada 1927 r. Rada Adwokacka w Warszawie ustaliła nawet wzór sprawozdań:

1. W jakiej dacie apl. adw. rozpoczął pracę w kancelarji?

2. Czy pracuje obecnie?

3. Jeśli nie, kiedy przestał pracować i dlaczego?

4. Czy w pracy tej były przerwy; jak długie i czem spowodowane?

72 Sprawozdanie Rady Adwokackiej 1934-1935, s. 96.

73 Tamże, s. 96.

74 Sprawozdanie Rady Adwokackiej 1935-1936, s. 119.

75 Sprawozdanie Rady Adwokackiej 1925-1926, s. 53.

76 Uchwała Rady Adwokackiej w Warszawie z dnia 28 października 1924 r.; Komunikat nr 1 Sprawozdania patronów o rodzaju zajęć i postępach aplikantów, „Palestra” 1924, R. I, nr 10, s. 537. 
5. Na czem polegają czynności apl. adw. - w szczególności:

Czy zastępuje patrona w sądach, jakich, jak często?

Czy zastępuje patrona w urzędach, jakich, jak często?

Czy wyręcza patrona w przyjmowaniu klientów?

Czy jest obecny podczas tych przyjęć?

Czy bywa codziennie w kancelarii patrona?

Ile czasu i w jakich godzinach poświęca pracy kancelaryjnej?

Czy redaguje projekty powództw, skarg, podań i innych pism?

Czy załatwia korespondencję patrona?

6. Czy poza pracą w kancelarii patrona apl. adw. ma inne zajęcie i jakie?

7. Czy apl. adw. zna obce języki i jakie?

8. Czy apl. adw. otrzymuje od patrona wynagrodzenie?

9. Uwagi o postępach apl. adw.

10. Uwagi szczególne $e^{77}$.

Ułatwieniu kontroli oraz opieki nad aplikantami miała sprzyjać nowa organizacja aplikacji przyjęta w 1937 r. (określona w Regulaminie aplikacji adwokackiej z 6 lipca 1937 r. $^{78}$ ). Polegała ona na podziale wszystkich aplikantów Izby Warszawskiej na 20-30-osobowe grupy. Na czele każdej z tych grup stał adwokat będący członkiem Komisji Aplikacji Adwokackiej, do którego obowiązków należały m.in.:

a) kontrola sprawozdań patronów i przestrzeganie składania ich ściśle w terminach, ustalonych przez Radę Adwokacką, żądanie w razie potrzeby dodatkowych danych i omawianie treści sprawozdania zarówno z patronami, jak i aplikantami, b) sprawdzanie, w miarę potrzeby, faktycznego odbywania aplikacji adwokackiej w kancelariach patronów i w sądach ${ }^{79}$.

Problem aplikacji pozornej dotyczył nie tylko Izby Warszawskiej, o czym świadczą działania NRA. Zgodnie z uchwałą podjętą przez nią 22 marca 1930 r. aplikanci odbywający aplikację pozorną mieli być wykreślani z listy, natomiast ich patroni - pociągani do odpowiedzialności dyscyplinarnej ${ }^{80}$. Tak surowe konsekwencje miały wpłynąć na likwidację tego zjawiska.

77 Komunikat nr 60 w sprawie sprawozdań patronów o zajęciach aplikantów adwokackich, „Palestra" 1927, R. IV, nr 12, s. 553.

78 Sprawozdanie Rady Adwokackiej 1936-1937, s. 9.

79 Sprawozdanie Rady Adwokackiej 1936-1937, s. 104.

80 Sprawozdanie Rady Adwokackiej 1930-1931, s. 84. 


\section{Wynagrodzenie aplikantów}

Z problemem aplikacji pozornej ściśle wiązało się zagadnienie wynagrodzenia aplikantów. W związku z tym, że adwokaci nie mieli obowiązku przyjmowania aplikantów, część z nich otrzymywała tylko skromne wynagrodzenie albo nie dostawała go w ogóle ${ }^{81}$.

Rada Adwokacka w Warszawie podjęła w tym zakresie uchwałę 7 kwietnia 1925 r., postulując, aby wysokość honorarium odpowiadała wynagrodzeniu otrzymywanemu przez aplikantów sądowych. Odpis uchwały przekazała NRA, prezydium sekcji adwokackiej Koła Prawników Polskich i zarządowi Oddziału Warszawskiego Związku Adwokatów Polskich ${ }^{82}$.

Sprawa wynagrodzenia nie została rozwiązana i ponownie powróciła w 1936 r., gdy Rada Adwokacka w Warszawie przekazała swoim członkom komunikat NRA z 25 stycznia tego roku, w którym ta przypominała patronom o obowiązku wynagradzania aplikantów, o ile ich praca przynosiła rzeczywistą korzyść. Komunikat ten został wystosowany na wniosek Związku Zrzeszeń Aplikantów Zawodów Prawniczych, co świadczy o powszechności tego problemu ${ }^{83}$.

Sytuacja zmieniła się dopiero po wejściu w życie nowelizacji z 1938 r., która zastrzegła na rzecz aplikantów prawo do wynagrodzenia ${ }^{84}$.

81 S. Płaza, Historia prawa..., cz. III, s. 724; M. Materniak-Pawłowska, Adwokatura II Rzeczypospolitej..., s. 182.

82 Komunikat w sprawie wynagradzania aplikantów adwokackich przez patronów, „Palestra” 1925, R. II, nr 5, s. 815-817.

83 Komunikat Nr 191 w sprawie przestrzegania zasady opłacania przez adwokatów-patronów pracy aplikantów adwokackich:

„Na posiedzeniu Wydziału Wykonawczego w dn. 25 stycznia 1936 r. Naczelna Rada Adwokacka rozpatrywała wniosek Rady Naczelnej Związku Zrzeszeń Aplikantów Adwokackich Zawodów Prawniczych, aby przypomnieć adwokatom-patronom o obowiązku wynagradzania aplikantów za ich pracę oraz zalecić branie pod uwagę przy udzielaniu zezwoleń na przyjęcie aplikanta okoliczności, czy aplikant będzie otrzymywał wynagrodzenie.

Naczelna Rada Adwokacka stanęła na tem stanowisku, że wynagrodzenie aplikanta adwokackiego jest obowiązkiem adwokata-patrona, gdy praca aplikanta przynosi rzeczywistą korzyść patronowi, w szczególności zaś gdy aplikant nie tylko pracuje w kancelarji adwokata-patrona, ale zastępuje go w sądach i urzędach; natomiast na początku aplikacji, kiedy początkujący aplikant zazwyczaj dopiero zapoznaje się z techniką pracy kancelaryjnej i zawodowej, zapewnienia aplikantowi wynagrodzenia nie można uznać za obowiązujące.

W związku z tem, w myśl zalecenia Naczelnej Rady Adwokackiej, Rada Adwokacka w Warszawie przypomina pp. członkom Izby, że adwokaci-patroni, odnoszący rzeczywistą korzyść z pracy zatrudnionych u nich aplikantów adwokackich, obowiązani są do odpowiedniego wynagradzania tej pracy”, „Palestra” 1936, R. XIII, nr 4, s. 300. Zob. Sprawozdanie Rady Adwokackiej 1935-1936, s. 63.

84 S. Płaza, Historia prawa..., cz. III, s. 724; A. Redzik, T.J. Kotliński, Historia adwokatury, s. 180. 


\section{Egzamin adwokacki}

Zgodnie ze Statutem Tymczasowym z 1918 r. po zakończeniu aplikacji należało zdać egzamin adwokacki, którego program określała NRA. Egzamin przeprowadzała komisja wyznaczona przez radę adwokacką w czasie i miejscu również przez nią wskazanym ${ }^{85}$.

Możliwość ponownego przystąpienia do egzaminu, w razie otrzymania oceny niedostatecznej, była ograniczona czasowo - należało to zrobić w ciągu dwóch lat. Nieprzystąpienie do egzaminu w tym terminie skutkowało wykreśleniem z listy aplikantów. Taki sam skutek powodowało ponowne otrzymanie oceny niedostatecznej ${ }^{86}$.

Prawo o ustroju adwokatury z 1932 r. bardziej szczegółowo regulowało zasady dotyczące przeprowadzania egzaminów. Egzamin odbywał się przed komisją egzaminacyjną „czynną przy radzie adwokackiej tego okręgu, w którym [aplikant - przyp. aut.] wpisany jest na listę" ${ }^{37}$. Artykuł 110 przewidywał następujący skład tej komisji:

1) dziekan lub wicedziekan rady adwokackiej, jako przewodniczący;

2) dwaj sędziowie sądu apelacyjnego, delegowani przez prezesa właściwego sądu apelacyjnego;

3) dwaj adwokaci delegowani przez radę adwokacką.

W razie potrzeby utworzenia kilku komisji rada adwokacka może delegować na przewodniczącego swego członka.

Ustawodawca w 1932 r. określił także formę i zakres egzaminu, który miał się składać zarówno z części pisemnej, jak i ustnej, a obejmować „wszystkie dziedziny prawa, których znajomość jest konieczna w zawodzie adwokackim"s8.

W przypadku niezdania egzaminu można było do niego ponownie przystąpić, jednak nie wcześniej niż przed upływem trzech miesięcy. Ponowne niezaliczenie egzaminu skutkowało możliwością przystąpienia do niego po raz trzeci wyłącznie pod warunkiem wyrażenia zgody przez komisję, przed którą aplikant zdawał drugi egzamin ${ }^{89}$. Ustawodawca nie wprowadził ograniczenia w postaci wymaganego upływu czasu między drugim a trzecim podejściem. Jednak zgodnie ze stanowiskiem Rady Adwokackiej w Warszawie wskazanie takiego okresu byłoby konieczne $\mathrm{z}$ uwagi na potrzebę rzetelnego przygotowania się aplikanta, zamierzającego po raz

85 Art. 17 Dekretu: „Aplikant adwokacki po ukończeniu aplikacji poddany będzie egzaminowi przed komisją według programu, ustalonego przez radę naczelną. Czas i miejsce egzaminu oraz członków komisji egzaminacyjnej wyznaczają rady adwokackie".

86 Art. 19 Dekretu: „Aplikant adwokacki, który nie zdał egzaminu, może przystąpić do ponownego egzaminu w ciągu dwóch lat następnych. Po upływie tego czasu lub w razie ponownego niezdania egzaminu może być wykreślony z listy”.

87 Art. 108 ust. 1 Prawa o ustroju adwokatury.

88 Art. 111 Prawa o ustroju adwokatury.

89 Art. 108 ust. 2 Prawa o ustroju adwokatury. 
kolejny do egzaminu przystąpić. W związku z tym 29 października 1935 r. Rada podjęła uchwałę, w której apelowała, aby komisje egzaminacyjne wyrażając zgodę na przystąpienie do egzaminu po raz trzeci, jednocześnie zastrzegały minimalny czas, jaki powinien upłynąć między kolejnymi egzaminami. Okres ten miałby być uzależniony od wyników uzyskanych przez kandydata w dwóch poprzednich podejściach. Uprawnienie komisji egzaminacyjnych do określania takiego czasu miało zaś wynikać z przysługiwania im dalej idącego prawa do odmowy udzielenia zgody na przystąpienie do egzaminu po raz trzeci ${ }^{90}$.

W praktyce dochodziło niekiedy do samowolnego przedłużania aplikacji i nieprzystępowania do egzaminu adwokackiego. Zjawisku temu starała się przeciwdziałać Rada, przyjmując następujące rozwiązanie:

1) co do aplikantów, którzy mimo dwuletniego terminu nie złożyli wcale podania o dopuszczenie do egzaminu, wzywać ich do Dziekana, celem wyjaśnienia powodów zwłoki;

2) co do aplikantów, którzy składali już egzamin adwokacki, ale z wynikiem niepomyślnym, o ile od owej daty upłynęło już dwa lata - uprzedzać o konieczności ponownego przystąpienia do egzaminu we wskazanym terminie, pod groźbą wykreślenia z listy;

3) co do aplikantów dopuszczonych do egzaminu, którzy nie przystąpili do tego egzaminu we wskazanym terminie bez usprawiedliwienia się lub bez uzyskania ze strony Rady odroczenia - zobowiązywać do poddania się egzaminowi w nowym wskazanym terminie pod groźbą wykreślenia $\mathrm{z}$ listy ${ }^{91}$.

Z drugiej strony zdarzało się, że podania o dopuszczenie do egzaminu składały osoby, które nie zakończyły jeszcze pełnego dwuletniego okresu aplikacji. W związku z dużą liczbą takich wniosków Rada Adwokacka w Warszawie podjęła 14 października 1930 r. decyzję, zgodnie z którą podania można było co do zasady składać wyłącznie po zakończeniu aplikacji. Dopuszczenie do egzaminu mimo niespełnienia tego wymogu mogło nastąpić tylko wyjątkowo, w uzasadnionych przypadkach, przy czym na takiego aplikanta miał być nakładany obowiązek dokończenia aplikacji po egzaminie ${ }^{92}$.

Początkowo egzaminy przeprowadzała stała komisja egzaminacyjna powoływana na dany rok. Na przykład 1 kwietnia 1930 r. powołano komisję w składzie: przewodniczący - dziekan J. Nowodworski, zastępca przewodniczącego - wicedziekan Z. Nagórski, członkowie: T. Bojanowicz, Cz. Białoszewicz, A. Chełmoński i M. Ettinger (byli oni członkami rady adwokackiej), do której mieli poza tym wchodzić kierownicy seminariów dla aplikantów oraz inni członkowie Izby zaproszeni przez nią ${ }^{93}$.

90 Sprawozdanie Rady Adwokackiej 1934-1935, s. 99-100.

91 Sprawozdanie Rady Adwokackiej 1925-1926, s. 53.

92 Sprawozdanie Rady Adwokackiej 1930-1931, s. 87.

93 Tamże. 
W kolejnych latach, w związku z dużą liczbą egzaminowanych, w ramach Izby Warszawskiej działały już dwie komisje egzaminacyjne, a ich przewodniczącymi byli odpowiednio dziekan i wicedziekan rady ${ }^{94}$.

Zwykle w danym okresie sprawozdawczym odbywały się trzy sesje egzaminacyjne $^{95}$, a wyniki egzaminów adwokackich składanych w kolejnych latach przedstawia tabela 2.

Tabela 2. Wyniki egzaminów

\begin{tabular}{|l|l|c|c|}
\hline \multicolumn{1}{|c|}{ Okres } & \multicolumn{1}{|c|}{$\begin{array}{c}\text { Liczba aplikantów } \\
\text { przystępujących do egzaminu }\end{array}$} & Zdali & Nie zdali \\
\hline I IV 1925 - 1 IV 1926 & 45 & 37 & 8 \\
\hline I IV 1927 - 1 IV 1928* & 54 & 42 & 12 \\
\hline I III 1928 - 15 II 1929 & 83 & 70 & 13 \\
\hline III-XI 1929 & 151 & 120 & 31 \\
\hline II 1930 - III 1931 & 245 (5 się wycofało) & 163 & 77 \\
\hline IV 1931 - III 1932 & 231 (5 się wycofało) & 164 & 62 \\
\hline I933 & 276 (7 się wycofało) & 209 & 60 \\
\hline III-XI 1934 & 216 (8 się wycofało) & 128 & 80 \\
\hline III-XI 1935 & 174 (14 się wycofało) & 103 & 57 \\
\hline II-X 1936 & 166 (13 się wycofało) & 97 & 56 \\
\hline III-XI 1937 & 213 (21 się wycofało) & 96 & 96 \\
\hline III 1938 & 98 (6 się wycofało) & 54 & 38 \\
\hline
\end{tabular}

*Nie uwzględniono liczby osób, które przystąpiły do egzaminu w marcu 1928 r., ponieważ wyniki zostały ogłoszone dopiero w kolejnym okresie sprawozdawczym. Te dane zostały uwzględnione w rubryce poniżej.

Źródto: Sprawozdanie Rady Adwokackiej w Warszawie za rok 1925-26 (za czas od IV 1925 do 1 IV 1926), Warszawa 1926, s. 55; Sprawozdanie Rady Adwokackiej w Warszawie za rok 1927-28 (za czas od 1 IV 1927 do 1 IV 1928 r.), Warszawa 1928, s. 58; Sprawozdanie Rady Adwokackiej w Warszawie za rok 1928-1929 (za czas od 1 III 1928 do 15 II 1929 r.), Warszawa 1929, s. 32; Sprawozdanie Rady Adwokackiej w Warszawie za rok 1929-1930 (za czas od 15 II 1929 do 15 II 1930 r.), Warszawa 1930, s. 39; Sprawozdanie Rady Adwokackiej w Warszawie za rok 1930-1931, Warszawa 1931, s. 88; Sprawozdanie Rady Adwokackiej w Warszawie za rok 1931-1932, Warszawa 1932, s. 79; Sprawozdanie Rady Adwokackiej w Warszawie za rok 1932-1933, Warszawa 1933, s. 98; Sprawozdanie Rady Adwokackiej w Warszawie za rok 1933-1934, Warszawa 1934, s. 93; Sprawozdanie Rady Adwokackiej w Warszawie za rok 1934-1935, Warszawa 1935, s. 102; Sprawozdanie Rady Adwokackiej w Warszawie za rok 1935-1936, Warszawa 1936, s. 125; Sprawozdanie Rady Adwokackiej w Warszawie za rok 1936-1937, Warszawa 1937, s. 111; Sprawozdanie Rady Adwokackiej w Warszawie za okres 1 XII 1937 - 1 VI 1938, Warszawa 1938, s. 65.

94 Np. Sprawozdanie Rady Adwokackiej 1934-1935, s. 101.

95 Np. Sprawozdanie Rady Adwokackiej 1930-1931, s. 7. 
W świetle tych danych wskazać można, że z biegiem czasu liczba osób, które nie zdały egzaminu adwokackiego, rosła. W 1937 r. osiągnęła nawet 50\% wszystkich osób do niego przystępujących. Świadczy to z jednej strony o słabym przygotowaniu aplikantów, z drugiej może wskazywać na poważne traktowanie wymagań przez komisję.

Tendencja ta występowała mimo działań podejmowanych przez Radę Adwokacką w Warszawie, która decyzją z 13 stycznia 1931 r. obciążyła patronów nowym obowiązkiem w postaci uczestniczenia przy ustnym egzaminie składanym przez zatrudnianych przez nich aplikantów. Obowiązek ten dotyczył głównie patronów zamieszkałych w Warszawie, a poza tym każdego, bez względu na miejsce zamieszkania, o ile przygotowywany przez niego aplikant otrzymał uprzednio ocenę niedostateczną i ponownie przystępował do egzaminu. Możliwość usprawiedliwienia nieobecności mogła wynikać tylko z „istotnej” przeszkody. Według rady adwokackiej nałożenie takiego obowiązku na adwokatów wynikało z potrzeby zorientowania się przez patronów w rezultatach pracy ich aplikantów oraz w zakresie wymagań stawianych na egzaminie adwokackim. Pierwsze egzaminy z udziałem patronów odbyły się w lutym i marcu 1931 r. ${ }^{96}$

\section{Zakończenie}

W II Rzeczypospolitej na ziemiach byłego zaboru rosyjskiego zachodziły znaczące przemiany w zakresie organizacji aplikacji adwokackiej i statusu aplikanta. Wiązały się one przede wszystkim z likwidacją aplikacji mieszanej, polegającej na konieczności odbycia najpierw aplikacji sądowej, a dopiero później adwokackiej. W konsekwencji czas aplikacji wynoszący, zgodnie ze Statutem Tymczasowym, dwa lata został wydłużony mocą Prawa o ustroju adwokatury do lat pięciu.

Aplikanci byli uważani za członków palestry, jednak ich uprawnienia były bardzo ograniczone. Początkowo mieli prawo do uczestniczenia w walnym zgromadzeniu, ale nie mogli się wypowiadać. W 1932 r. takie uprawnienie uzyskali, lecz w dalszym ciągu nie posiadali prawa do udziału w głosowaniach.

Do ich obowiązków należała praca w kancelarii patrona oraz uczestniczenie w zajęciach. Ze sprawozdań Rady Adwokackiej w Warszawie wynika, że jednym z zasadniczych problemów znacznej części aplikantów było niewysokie wynagrodzenie albo jego brak. W związku z tym niektórzy z nich nie wykonywali swoich obowiązków. Tym samym pogłębiał się problem tzw. aplikacji pozornej, który mimo działań podejmowanych przez Radę nie został zlikwidowany. 
Trudności, z jakimi borykali się aplikanci adwokaccy, wiązały się również z organizacją przeznaczonych dla nich zajęć. Przede wszystkim należy podkreślić, że zajęcia te odbywały się niemal wyłącznie w Warszawie. W pozostałych miastach Izby Warszawskiej przeprowadzano je incydentalnie.

Zajęcia były prowadzone w zbyt licznych grupach, choć rada adwokacka próbowała temu przeciwdziałać, przeprowadzając kolejne reformy. Na uznanie zasługuje dobór osób prowadzących seminaria, wśród których odnaleźć można wybitnych prawników dwudziestolecia międzywojennego. Również sami aplikanci Izby Warszawskiej podjęli inicjatywę $\mathrm{w}$ zakresie lepszego przygotowania do zawodu i w 1934 r. wystąpili z wnioskiem o organizowanie seminariów, które miałyby uzupełniać zajęcia organizowane przez Radę. Propozycja znalazła uznanie Rady. Nie wpłynęło to jednak korzystnie na wyniki egzaminu adwokackiego, którego w niektórych latach nie zdawała nawet połowa przystępujących.

\section{Bibliografia}

\section{Źródta}

Dekret w przedmiocie statutu tymczasowego Palestry Państwa Polskiego z 24 XII 1918 r. (Dz.U. $1918 \mathrm{Nr} 22$ poz. 75).

Komunikat nr 1 Sprawozdania patronów o rodzaju zajęć i postępach aplikantów, „Palestra” 1924, R. I, nr 10, s. 537.

Komunikat nr 34 w przedmiocie ograniczenia aplikantów $w$ wyborze patrona lub też adwokatów w przyjmowaniu tej lub innej liczby aplikantów, „Palestra” 1926, R. III, nr 6, s. 292.

Komunikat nr 60 w sprawie sprawozdań patronów o zajęciach aplikantów adwokackich, „Palestra" 1927, R. IV, nr 12, s. 553.

Komunikat nr 94 w sprawie ograniczeń co do podejmowania się przez adwokatów obowiązków patronów, „Gazeta Sądowa Warszawska” 1930, nr 17, s. 246.

Komunikat w sprawie wynagradzania aplikantów adwokackich przez patronów, „Palestra” 1925, R. II, nr 5, s. 815-817.

Komunikat $n r 97$ w sprawie rozkładu zajęć w seminariach dla aplikantów adwokackich na okres 1930/31, „Palestra” 1930, R. VII, nr 6-7, s. 333-335.

Komunikat nr 99 w sprawie ograniczeń co do podejmowania się przez adwokatów obowiązków patronów aplikantów adwokackich, „Palestra” 1930, R. VII, nr 8-9, s. 422-423.

Komunikat nr 133 w sprawie podejmowania się przez adwokatów obowiązków patrona, „Palestra" 1933, R. X, nr 6-7, s. 434-435.

Komunikat nr 191 w sprawie przestrzegania zasady opłacania przez adwokatów-patronów pracy aplikantów adwokackich, „Palestra” 1936, R. XIII, nr 4, s. 300.

Orzeczenie Naczelnej Rady Adwokackiej z dnia 9 października 1926 r., „Palestra” 1927, R. IV, nr 2, s. 66-76. 
Rozporządzenie Prezydenta Rzeczypospolitej z dnia 7 października 1932 r. Prawo o ustroju adwokatury (Dz.U. $1932 \mathrm{Nr} 86$ poz. 733).

Sprawozdanie Rady Adwokackiej w Warszawie za rok 1925-1926 (za czas od IV 1925 do 1 IV 1926), Warszawa 1926.

Sprawozdanie Rady Adwokackiej w Warszawie za rok 1927-28 (za czas od 1 IV 1927 do 1 IV 1928 r.), Warszawa 1928.

Sprawozdanie Rady Adwokackiej w Warszawie za rok 1928-1929 (za czas od 1 III 1928 do 15 II 1929 r.), Warszawa 1929.

Sprawozdanie Rady Adwokackiej w Warszawie za rok 1929-1930 (za czas od 15 II 1929 do 15 II 1930 r.), Warszawa 1930.

Sprawozdanie Rady Adwokackiej w Warszawie za rok 1930-1931, Warszawa 1931.

Sprawozdanie Rady Adwokackiej w Warszawie za rok 1931-1932, Warszawa 1932.

Sprawozdanie Rady Adwokackiej w Warszawie za rok 1932-1933, Warszawa 1933.

Sprawozdanie Rady Adwokackiej w Warszawie za rok 1933-1934, Warszawa 1934.

Sprawozdanie Rady Adwokackiej w Warszawie za rok 1934-1935, Warszawa 1935.

Sprawozdanie Rady Adwokackiej w Warszawie za rok 1935-1936, Warszawa 1936.

Sprawozdanie Rady Adwokackiej w Warszawie za rok 1936-1937, Warszawa 1937.

Sprawozdanie Rady Adwokackiej w Warszawie za okres 1 XII 1937 - 1 VI 1938, Warszawa 1938.

Zatrudnienie aplikantów adwokackich, „Palestra” 1930, R. VII, nr 5, s. 223-224.

\section{Literatura}

Historia państwa i prawa Polski, t. III: Od rozbiorów do uwłaszczenia, red. J. Bardach, M. Senkowska-Gluck, Państwowe Wydawnictwo Naukowe, Warszawa 1981.

Kisza A., Krzemiński Z., Łyczywek R., Historia adwokatury polskiej, M. C. Kwadrat, Warszawa 1995.

Kotliński T.J., Samorząd adwokacki w Drugiej Rzeczypospolitej, Naczelna Rada Adwokacka, Warszawa 2008.

Krzemiński Z., Kartki z dziejów warszawskiej adwokatury, Wolters Kluwer Business, Warszawa 2008.

Materniak-Pawłowska M., Adwokatura II Rzeczypospolitej. Zagadnienia prawno-ustrojowe, Wydawnictwo Naukowe Uniwersytetu im. Adama Mickiewicza, Poznań 2009.

Płaza S., Historia prawa w Polsce na tle porównawczym, cz. I: X-XVIII w., cz. II: Polska pod zaborami, cz. III: Okres międzywojenny, Księgarnia Akademicka, Kraków 2001-2002.

Redzik A., Kotliński T.J., Historia adwokatury, Naczelna Rada Adwokacka - Redakcja „Palestry", Warszawa 2018. 